\title{
EFFICIENCY ESTIMATION OF A WASTEWATER TREATMENT PLANT IN AN INDUSTRY IN KALININGRAD
}

\author{
Maria Shevtsova \\ Sergey Umansky \\ Kaliningrad State Technical University, Russia
}

\begin{abstract}
The main objective of this study is the industrial establishment "System". This study also aims to estimate the influence of machine - building plants in the environment. Recommendations and conclusions were given for the improvements of ecological situation. There are various problems concerning the protection of the environment. Pollution is the main problem. Plant "System" influences negative effect upon air, water and its quality. Waste products of different classes of danger, which are formed on the industrial establishment "System", pollute soils of districts. It is necessary to devise different methods for improving the ecological situation. There are various measures to be done to prevent the environmental pollution
\end{abstract}

\section{KEYWORDS}

Environment; Pollution; Wastewater treatment plant; Heavy metals pollution; Eutrophication.

\section{INTRODUCTION}

Kaliningrad district is a highly developed industrial region. Mechanical engineering companies play the important role in the economy of this region. One from such companies is the enterprise "Systema" which produces the equipment for banks. The technological process of production is complex and multi-stage. It needs a lot of raw materials. As a result, this industrial activity has negative effects on the environment: air and water pollution, extension territories for waste products. For estimation of treatment plant's efficiency, it is necessary to analyze the enterprise's impact on the water bodies.

\section{TREATMENT PLANT OF SYSTEMA COMPANY}

The enterprise consumes about $107.00 \mathrm{~m}^{3} /$ year of water, water irrevocable losses are 0.40 $\mathrm{m}^{3} /$ year.

The enterprise has waste water treatment plant which was built in 1974. Treatment system is shown in Figure 1. 


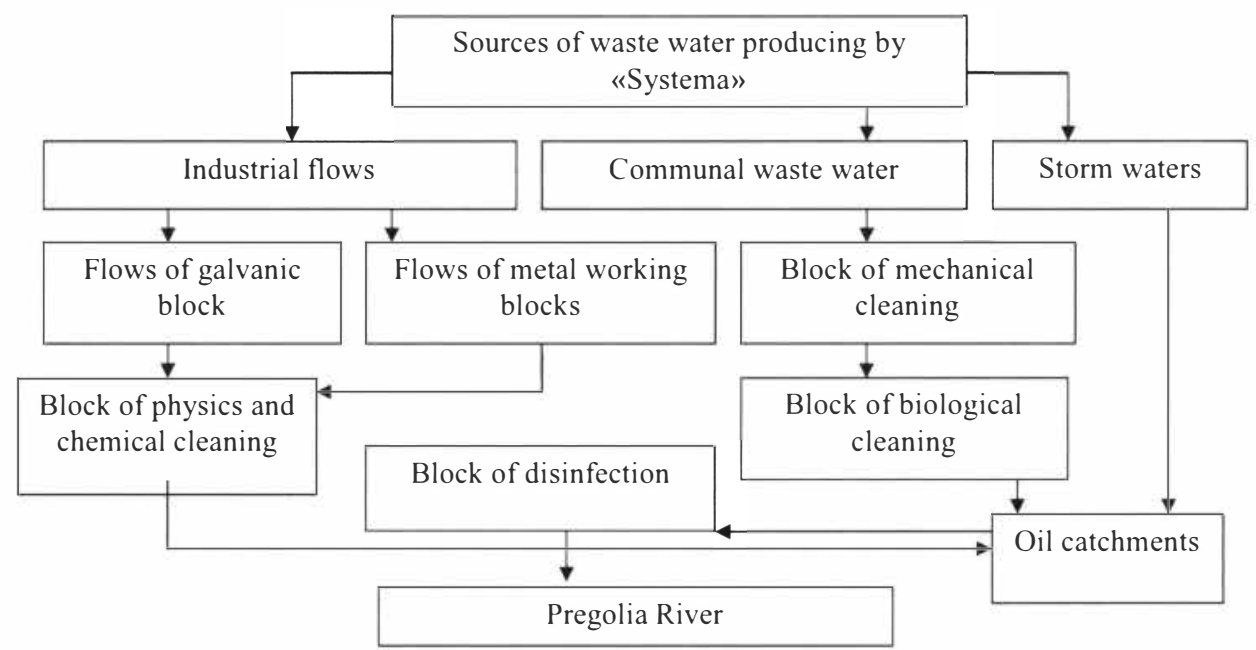

Figure 1. Scheme of Systema's treatment plant.

Flows are coming in installation of mechanical treatment which productivity is $1,300 \mathrm{~m}^{3} /$ day. It is four section horizontal setting tank oil detectors. Siphons with the filters for the refinements of flows from oil products are installed between sections.

\subsection{Block of biological cleaning}

The total biological treatment of communal flows is realized on the compact installation with productivity of $700 \mathrm{~m}^{3} / \mathrm{day}$. It includes three blocks; two from them are zone of aeration, zone of aerobic fermentation of sedimentation. Wastewater goes to canalization pumping station and then transferred by pumps to the treatment plant through the wells of pressure extinguishers. Then wastewater goes on the trough where filtration is going on and then to canal with active sludge for biological treatment. There is the grid installed before trough for catching large pieces of trash coming to the canalization system. From canal draft treated water goes to reservoir for sedimentation. Here, mechanic particles settle down. Then water goes to the canal for disinfection and to the Pregolia River.

When active sludge exudes maximum volume part of it removes to the sludge cards designed as gravel filter. Here water gets off from sludge and disinfected by bleaching powder. The effectiveness of the biological treatment block decreases in autumn period and does not work during the summer.

\subsection{Block of chemical cleaning}

Chemically polluted industrial water from galvanic block and production of printed matrixes which contains heavy metal ions in its compound goes to the physics and chemical treatment process based on the electrochemical method. The productivity of this treatment plant is 695 $\mathrm{m}^{3} /$ day. Chemically polluted water comes to the accumulating volume and then to 10 electro coagulators with capacity of $5.5 \mathrm{~m}^{3} /$ hour for each. After that water goes to the setting tank 
where the supplementary machining by staked lime is produced. Its capacity is $180 \mathrm{~m}^{3}$. Storm water and melted water are mixed with the communal and industrial flows and are treated in oil catch. Water refined from oil is thrower down river Pregolia.

\section{ANALYSIS OF WASTEWATER}

The analysis of wastewater content on this enterprise's outflow has showed that the concentrations of the main fixed parameters for treated water are exceeded established norms for these parameters (Table I).

Table 1. Composition and quality of sewage of the enterprise.

\begin{tabular}{cccc}
\hline Monitoring parameter & Treated water, $\mathrm{mg} / \mathrm{L}$ & Fishery MAC, $\mathrm{mg} / \mathrm{L}$ & Repetition of increasing \\
\hline BOD $_{\text {tor }}$ & 14.84 & $<3$ & 4.96 \\
\hline Oil-product & 0.04 & 0.05 & - \\
\hline Phosphates & 0.34 & 0.15 & 2.26 \\
\hline Iron & 0.33 & 0.1 & -3 \\
\hline Sulphates & 65.73 & 100.0 & 1.6 \\
\hline Nitrogen & 0.80 & 0.50 & 21 \\
\hline Chlorine & 34.28 & 300.0 & - \\
\hline Nickel & 0.21 & 0.01 & 20 \\
\hline Dissolved oxygen & 11.86 & $<6.0$ & \\
\hline Copper & 0.02 & 0.001 & \\
\hline
\end{tabular}

\subsection{The dynamic concentrations of the biogens}

Due to an excess by enterprise's wastewater of normative requirements there is a threat for Pregolia River for heavy metals pollution and eutrophication (Figure 2-5).

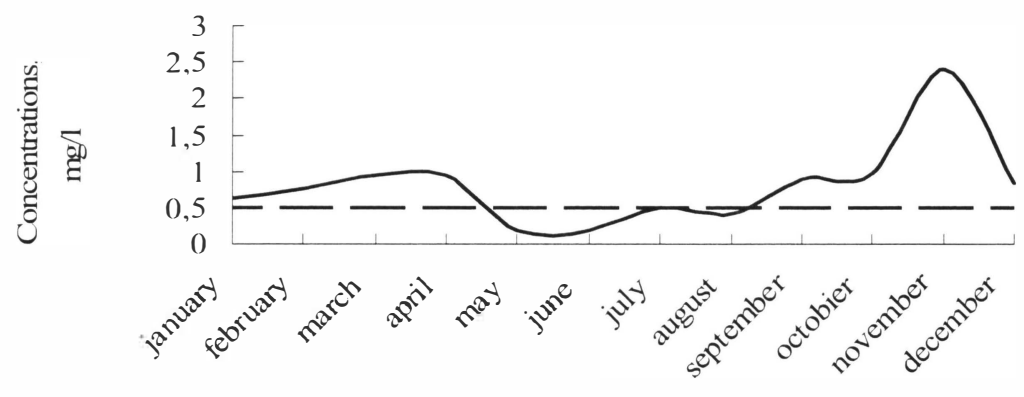

Months

- Analitical concent of nitrogen - - Normative conctnt of nitrogen

Figure 2. The dynamic of nitrogen content in wastewater of Systema during a year. 
The dynamic content of nitrogen is exceeded MAC 1.4 times in wastewater. The least content of this parameter is observed in the spring - summer period. The content of phosphates in industrial flows is varied about 2.26 MAC (Figure 3).

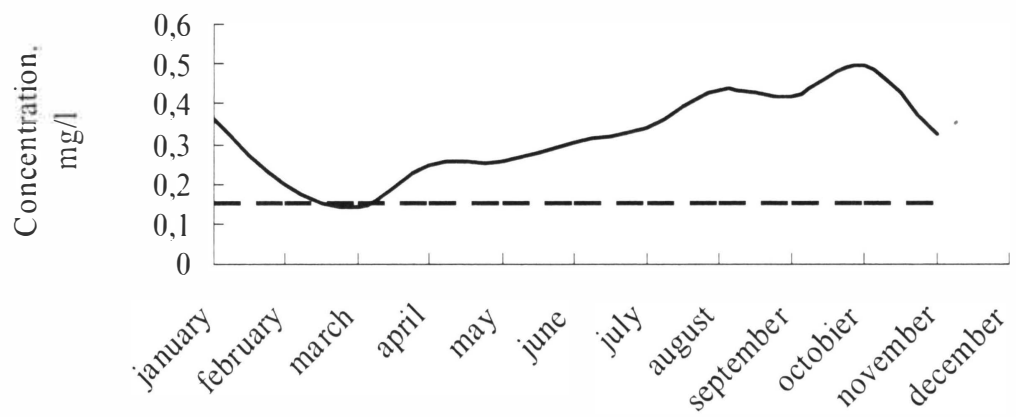

Months

— Analitican concent of phosphates - - Nomative content of phosphates

Figure 3. The dynamic of phos phates content the flow's of Systema during a year.

\subsection{The dynamic the concentrations for the heavy metals}

Figure 4 shows the dynamics of nickel content in industrial flows during a year. It was observed that the industrial flows of the enterprise (in average $0.21 \mathrm{mg} / \mathrm{L}$ during a year) exceeded the normative parameter $(0.01)$ in several tames (in average $21 \mathrm{MAC}$ ).

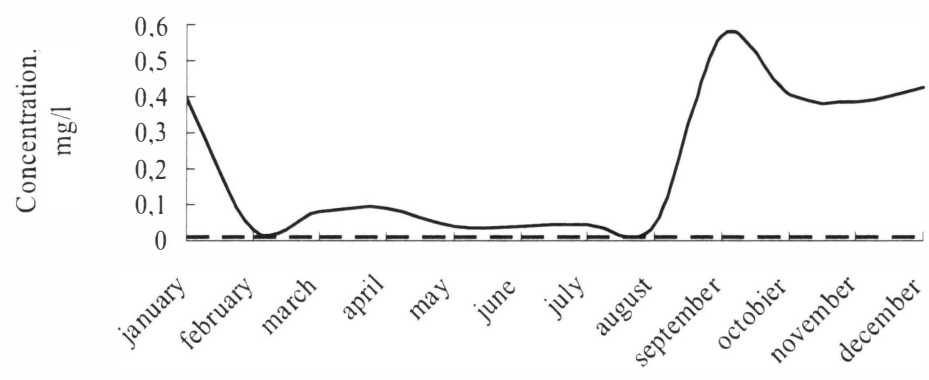

Monthsc

- Analytical contrnt of nickel - - Normative content of nickel

Figure 4. The dynamics of nickel content in the flow's of Systema during a year. 


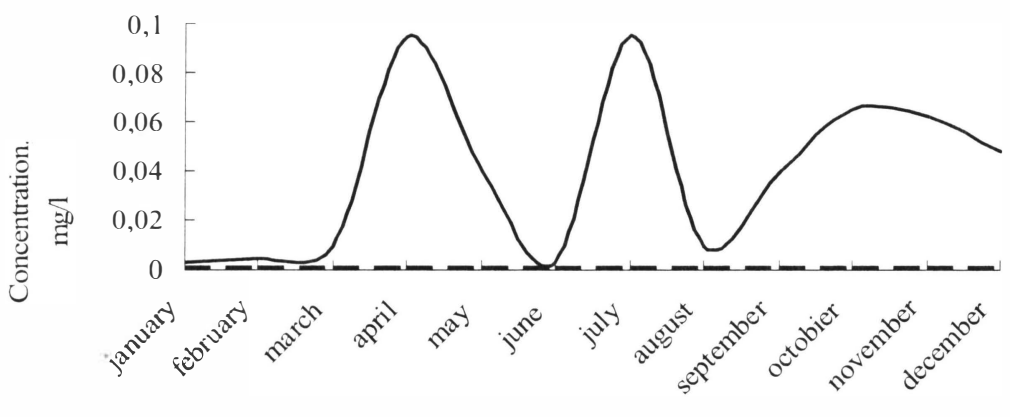

Months

— Analitical content of cooper - - Normative content of cooper

Figure 5. The dynamics of cooper content of in the flow's of Systema during a year.

\section{CONCLUSIONS}

So, the concentration of researched substances reached its maximum in winter months and is reduced in summer months. This dynamic content of soiled substances is dependent on the work of enterprises. The work of enterprise was more intensive in autumn-winter period than in spring-sumener period. The enterprise had the great quantity of orders for the production of machines for the account of money. There was the failing off production in spring-summer period, so the quantity of soiled substances was reduced.

The low concentration of researched parameters in industrial flows is explained of failing off of production. Wastewater treatment plant work in incomplete regimen because the average daily load on the system of refining is $200 \mathrm{me} /$ day instead of $800 \mathrm{me} / \mathrm{day}$. The results of effectiveness analysis show that there is exceeding of MACs for several parameters due to ineffective operation of waste water treatment plant. There is no worker who is responsible for the exploitations of wastewater treatment plant, the normative documents were not prepared for the rules of exploitation the wastewater treatment system.

The system of ecological monitoring is not effective. That is why Systema pays about 1.8 $\mathrm{mln}$. rubles for the exceeding established norms. It is 5\% from yearly expenditures of Systema for production activity.

\section{REFERENCES}

[1] Ансеров Ю.М., Дурнев В.Д. Машиностроение и охрана окружаюшей природной среды. - JI., 1979. - 224c.

[2] Водогрецкий В.Е. Антропогенное изменение стока рек. - Л., 1990. -325с. 
[3] Водоёмы Калининградской области. Оценка экологического состояния. Проект Tacis ENVRUS 9803. - Калининград, 2000. - 47c.

[4] Водоснабжение и водоотведение жилых и общественных зданий.- Калининград, 1997. - 293 c.

[5] Доклад о состоянии и об охране окружающей среды Калининградской области в 2003 г. / Управление природных ресурсов и охраны окружающей среды МПР России по Калининградской области - Калининград, 2004. - 216 с.

[6] ЕКАТ-Калининград. Экологическая ситуация в Калининграде. Калининград: Янтарный сказ, 2000. - 32 с.

[7] Защита окружающей среды от техногенного воздействия / Под ред. и с предисловием Г.Ф. Невской. - М., 1993. - $216 \mathrm{c}$.

[8] Каталюг технологий: Передовые технологии России. - http:// www.briket.ru.

[9] Мазур И.И., Молдаванов О.И. Курс инженерной экологии. - М.: Высшая школа, 1999. - 447c.

[10] Небел Б. Наука об охране окружающей среды. - М., 1993. - Т.2. - 214c.

[11] Перечень рыбохозяйственных нормативов: Предельных допустимых концентраций (ІІДК) и ориентировочно безопасных уровней воздействия (ОБУВ) вредных вешеств для водных объектов, имеющих рыбохозяйственное значение. М.: ВНИРО, 1999. - 304c.

[12] Петрова А. П. И снова о Калининградской области // Хроники Амбера. - 2003. 11 июня.

[13] Программа производственного экологического контроля за источниками загрязнений водных объектов. - Калининград, 2000.

[14] Проектирование машиностроительных заводов: Справочник / Под ред. Е.С. Ямпольского. - М: Машиностроение, 1974. -Т. 5. - 437с.

[15] Розанов С.И. Общая экология. - СПІ., 2001. - 288 с.

[16] Смирнов С.А., Запарий М.М. Компактные очистные сооружения гальванических участков // Экология и промышленность России. - М., 2005. - С. 32-35.

[17] Форма 2 - ТП-водхоз. 2004 г.

[18] Экологический атлас города Калининграда. - Калининград, 1999. 